Penelitian

\title{
Prevalensi Kecacingan pada Usus Ayam Kampung di Pasar Tradisional Jakarta dan Kota Bogor
}

\section{Prevalence of Gastrointestinal Endoparasites in Free-range chicken at Traditional Market Jakarta and Bogor}

\author{
Suryaningtyas Kusumadewi ${ }^{{ }^{*}}$, Risa Tiuria ${ }^{2}$, Ridi Arif ${ }^{2}$ \\ ${ }^{1}$ Program Sarjana Kedokteran Hewan Fakultas Kedokteran Hewan, \\ Institut Pertanian Bogor, Indonesia \\ ${ }^{2}$ Staf Pengajar Divisi Parasitologi dan Entomologi Kesehatan, Departemen Ilmu Penyakit Hewan dan Kesehatan \\ Masyarakat Veteriner, Fakultas Kedokteran Hewan, Institut Pertanian Bogor, Indonesia \\ *Penulis untuk korespondensi: risatiprio@gmail.com \\ Diterima 7 Januari 2019, Disetujui 21 Oktober 2019
}

\begin{abstract}
ABSTRAK
Penelitian ini bertujuan untuk mengidentifikasi dan mengukur prevalensi kecacingan di usus ayam kampung yang ada di pasar tradisional Jakarta dan Kota Bogor. Usus ayam kampung diambil dari 5 pasar yang ada di Jakarta (Bendungan Hilir, Palmerah, Pasar Minggu, Pluit, dan Jatinegara) dan di 4 pasar yang ada di Kota Bogor (Anyar, Bogor, Jambu Dua, Gunung Batu). Sampel yang diambil sebanyak 5 sampel di setiap pasar dengan total 45 sampel. Hasil penelitian menunjukkan 28 dari 45 sampel usus ayam kampung (Gallus domesticus) yang diperiksa di pasar tradisional Jakarta dan Bogor positif mengalami kecacingan. Hasil prevalensi menunjukkan pasar Jakarta sebesar $56 \%$ dan pasar Bogor sebesar 70\%. Prevalensi berdasarkan jenis-jenis cacing di Pasar Jakarta adalah; Railletina echinobothrida (52\%), Heterakis gallinnarum (32\%), Railletina tetragona (24\%), Hymenolepis carioca (16\%), Ascaridia galli (16\%), dan Hymenolepis cantaniana (4\%). Prevalensi berdasarkan jenis-jenis cacing yang ditemukan di Pasar Bogor adalah Railletina echinobothrida (70\%), Railletina tetragona (55\%), Heterakis gallinarum (10\%), Hymenolepis carioca (30\%), Hymenolepis cantaniana (20\%), dan Railletina cesticillus (20\%).
\end{abstract}

Kata kunci: ayam kampung, Bogor, endoparasit, Jakarta, pasar tradisional

\begin{abstract}
This study aimed to identify and measure the prevalence of endoparasites in free-range chicken (Gallus domesticus) intestine from traditional markets in Jakarta and Bogor. The chicken intestines were collected from 5 traditional markets in Jakarta (Bendungan Hilir, Palmerah, Pasar Minggu, Pluit, and Jatinegara) and 4 traditional markets in Bogor (Anyar, Bogor, Jambu Dua, and Gunung Batu). Five samples of chicken intestine were examined from each market and the total number of samples collected were 45 . The results showed that 28 out of 45 samples of free-range chicken (Gallus domesticus) intestine in Jakarta and Bogor traditional markets were positive with endoparasites. The prevalence results showed that the Jakarta markets was $56 \%$ and Bogor markets was $70 \%$. The prevalence by type of endoparasites in Jakarta traditional market found in the form; Railletina echinobothrida (52\%), Heterakis gallinnarum (32\%), Railletina tetragona (24\%), Hymenolepis carioca (16\%), Ascaridia galli (16\%), and Hymenolepis cantaniana (4\%). The prevalence results showed in Bogor traditional markets found in the form; Railletina echinobothrida (70\%), Railletina tetragona (55\%), Heterakis gallinarum (10\%), Hymenolepis carioca (30\%), Hymenolepis cantaniana (20\%), and Railletina cesticillus (20\%).
\end{abstract}

Keywords: Bogor, endoparasites, free range chicken, Jakarta, traditional market 


\section{PENDAHULUAN}

Perkembangan populasi manusia mengakibatkan peningkatan kebutuhan pangan yang berkualitas dan bernilai gizi baik. Hal tersebut didukung dengan semakin bertambahnya pengetahuan masyarakat akan pentingnya gizi yang baik bagi tubuh manusia. Salah satu permintaan pangan yang meningkat adalah protein hewani alami (organik). Ayam merupakan salah satu kebutuhan protein hewani alami yang sering dicari masyarakat. Ayam kampung adalah ayam yang paling banyak dipelihara oleh masyarakat. Pemeliharaannya yang mudah dan terhitung murah membuat masyarakat memilih untuk memelihara ayam kampung.

Daging ayam kampung memiliki kandungan lemak lebih rendah dibandingkan ayam ras. Kandungan tersebut menjadikan ayam kampung terasa enak sehingga masyarakat sangat menyukainya. Daging ayam kampung juga memiliki tekstur yang keras sehingga tidak mudah hancur saat diolah. Daging ayam kampung yang keras disebabkan karena ayam kampung hidup secara bebas sehingga membantu pertumbuhan otot dan sedikitnya akumulasi lemak (Suhaila et al. 2015).

Pemeliharaan ayam kampung yang dibiarkan bebas di lingkungan membuat ayam lebih mudah terserang penyakit. Masalah kesehatan yang sering dialami ayam kampung adalah infeksi endoparasit. Endoparasit yang biasa menyerang saluran pencernaan unggas adalah Nematoda (Ascaridia sp, Heterakis sp, Tetrameres sp, dan Capillaria sp), Cestoda (Railletina sp), dan Trematoda (Echinostoma sp dan (atatropis sp).

Penyebaran endoparasit terhadap ternak unggas dapat melewati media pakan, air, dan peralatan ternak yang terkontaminasi (Parede et al. 2005). Kasus kecacingan pada ayam kampung umumnya bersifat sub akut dan jarang mengakibatkan kematian. Namun, kecacingan dapat menyebabkan penurunan produksi telur, penurunan bobot badan, gangguan pertumbuhan, kelemahan dan depresi sehingga menimbulkan kerugian ekonomi (Loliwu dan Thalib 2012).

Tingginya permintaan ayam kampung di masyarakat membuat tempat pemotongan ayam kampung di pasar tradisional masih banyak diminati. Pemotongan ayam di pasar tradisional masih dilakukan secara sederhana dengan tempat seadanya dan kebersihan yang kurang diperhatikan. Lokasi tempat penampungan ayam sementara dekat dengan tempat dimana ayam dipotong. Pengeluaran darah yang kurang sempurna juga sering terjadi, sehingga banyak daging ayam kampung yang dagingnya lebih cepat rusak dan busuk. Tempat penampungan ayam sementara yang kotor dan seperti kurang terawat juga dapat menjadi salah satu faktor ayam tertular penyakit dari ayam lain.

Sulitnya identifikasi kasus kecacingan pada ayam kampung mengakibatkan sulitnya pelaksanaan program pengendalian. Pengendalian dapat efektif dilakukan jika terdapat informasi yang tepat mengenai kasus kecacingan ini. Maka dari itu, perlu dilakukannya pengukuran prevalensi kecacingan yang menyerang ayam kampung di Pasar Tradisional. Penelitian ini bertujuan untuk mengidentifikasi dan mengukur prevalensi cacing di usus ayam kampung di Pasar Tradisional Jakarta dan Bogor. Hasil penelitian ini diharapkan dapat memberikan informasi mengenai kesehatan ayam kampung khususnya di Pasar Tradisional Jakarta dan Bogor.

\section{BAHAN DAN METODE}

\section{Bahan dan Alat}

Bahan yang digunakan adalah 5 usus ayam dari setiap pasar, aquades, alkohol 70\%, pewarna Semichon's Acetocarmine, dan minyak cengkeh. Alat yang digunakan dalam penelitian ini adalah mikroskop, seperangkat alat bedah, cawan petri, botol plastik, plastik, sarung tangan, dan cool box.

\section{Sampel}

Penelitian ini menggunakan teknik Penarikan Contoh Acak Sederhana (Simple random sampling) sebagai metode pengambilan sampel. Banyaknya sampel yang diambil dari setiap lokasi pasar adalah 5 sampel usus ayam. Usus ayam kampung diambil dari tempat pemotongan ayam kampung di pasar tradisional Jakarta dan Bogor. Pasar tradisional tersebut adalah Pasar Bendhil, Palmerah, Pasar Minggu, Pluit, Jatinegara, Anyar, Bogor, Jambu Dua, dan Gunung Batu.

\section{Prosedur}

Setiap bagian usus ayam dimasukkan kedalam plastik berisi air yang diberi nomor dan dimasukkan ke dalam coolbox. Usus tersebut dibawa ke Laboratorium Helmintologi, Fakultas Kedokteran hewan IPB.

Usus ayam tersebut dipisahkan antara usus halus, usus besar beserta sekum dan rektum. Pada waktu pemeriksaan, bagian usus diletakkan diatas gabus yang terlebih dahulu dilapisi plastik hitam, kemudian usus dibuka secara perlahan menggunakan 
alat bedah. Cacing-cacing dewasa di setiap bagian usus dikumpulkan kedalam cawan petri yang berisi aquades. Cacing-cacing berukuran besar dihitung tanpa bantuan mikroskop sedangkan cacing-cacing berukuran kecil dihitung dibawah 'dissecting microscope'. Cacing-cacing tersebut disimpan dalam etanol $70 \%$ dalam botol-botol plastik yang diberi label.

Cacing dibagi menjadi nematoda dan cestoda. Cacing cestoda diwarnai dengan pewarnaan Semichon's Acetocarmin sedangkan Nematoda akan diwarnai dengan Minyak Cengkeh. Setelah itu cacing diamati dan ditentukan spesiesnya dibawah mikroskop.

\section{Analisis Data}

Data berupa jenis cacing yang ditemukan dianalisis secara deskriptif. Data yang diperoleh secara kuantitatif yaitu prevalensi endoparasit diolah menggunakan Ms. Excel 2013. Data jumlah populasi cacing dianalisis dengan Analysis of Variance (ANOVA) One Way kemudian dilanjutkan dengan uji Fisher menggunakan aplikasi Minitab 18.

\section{HASIL}

Hasil pemeiksaan di laboratorium menunjukkan 28 dari 45 sampel usus ayam yang diperiksa positif mengalami kecacingan. Prevalensi ayam yang terinfeksi di pasar di Bogor dan Jakarta memiliki perbedaan yang signifikan. Rata-rata prevalensi di pasar Jakarta sebesar $56 \%$ (Tabel 1) sedangkan pasar yang ada di Kota Bogor sebesar 70\% (Tabel 2). Hal ini menunjukkan bahwa ayam kampung yang dijual di pasar tradisional Bogor memiliki prevalensi keca- cingan yang lebih tinggi dibandingkan pasar tradisional di Jakarta.

Rataan populasi kelas nematoda paling tinggi berada pada pasar Palmerah dan pasar Pasar Minggu di Jakarta (Tabel 3). Sedangkan hasil rataan kelas cestoda paling tinggi berada pada pasar Anyar di Bogor (Tabel 3). Cacing kelas cestoda merupakan cacing yang paling sering ditemukan di penelitian ini. Jenis cacing yang paling sering menyerang ayam kampung dari kedua daerah adalah Railletina echinobothrida (Tabel 4).

Hasil penelitian pada Tabel 5 menunjukkan rataan jumlah cacing terbanyak di pasar daerah Jakarta adalah Heterakis gallinarum. Sedangkan rataan jumlah cacing terbanyak di pasar daerah Bogor adalah Railletina echinobothrida (Tabel 5). Berdasarkan hasil pemeriksaan terdapat tujuh spesies cacing yang ditemukan. Ketujuh spesies tersebut berasal dari kelas nematoda dan cestoda. Spesies kelas cestoda yang ditemukan adalah, Railletina cesticillus, Railletina echinobothrida, dan Railletina tetragona (Gambar 1) Hymenolepis cantaniana, Hymenolepis carioca (Gambar 2).

\section{PEMBAHASAN}

\section{Prevalensi Kecacingan berdasarkan Lokasi Pasar}

Hasil penelitian di pasar tradisional Jakarta dan Bogor menunjukkan 28 dari 45 sampel usus ayam yang diperiksa positif mengalami kecacingan. Hal ini juga terjadi di desa Taenade dan Tomata, Sulawesi tengah, yang menunjukkan dari 80 sampel feses ayam yang diuji 55 mengalami kecacingan (Loliwu dan Thalib 2012). Demikian juga penelitian di pasar

Tabel 1 Prevalensi (\%) kecacingan berdasarkan lokasi pasar di Jakarta

\begin{tabular}{|c|c|c|c|}
\hline Pasar di Jakarta & Jumlah Sampel & Ayam Terinfeksi & Prevalensi \\
\hline Bendungan Hilir & 5 & 4 & 80 \\
\hline Palmerah & 5 & 4 & 80 \\
\hline Pasar Minggu & 5 & 5 & 100 \\
\hline Pluit & 5 & 0 & 0 \\
\hline Jatinegara & 5 & 1 & 20 \\
\hline \multicolumn{2}{|c|}{ Rata-rata } & & 56 \\
\hline
\end{tabular}

Tabel 2 Prevalensi (\%) kecacingan berdasarkan lokasi pasar di Bogor

\begin{tabular}{|c|c|c|c|}
\hline Pasar di Bogor & Jumlah Sampel & Ayam Terinfeksi & Prevalensi \\
\hline Anyar & 5 & 3 & 60 \\
\hline Bogor & 5 & 3 & 60 \\
\hline Jambu Dua & 5 & 3 & 60 \\
\hline Gunung Batu & 5 & 5 & 100 \\
\hline \multicolumn{2}{|c|}{ Rata-rata } & & 70 \\
\hline
\end{tabular}


4 | Kusumadewi et al.

Tabel 3 Jumlah cacing (ekor) di setiap lokasi pasar

\begin{tabular}{|c|c|c|}
\hline \multirow{2}{*}{ Lokasi Pasar } & \multicolumn{2}{|c|}{ Jenis Parasit } \\
\hline & Nematoda & Cestoda \\
\hline Bendhil & $4.60 \pm 9.74^{b}$ & $7.83 \pm 5.12^{c}$ \\
\hline Palmerah & $32.20 \pm 37.88^{a}$ & $1.67 \pm 1.21^{c}$ \\
\hline Pasar Minggu & $75.00 \pm 158.91^{a}$ & $23.50 \pm 19.77^{\mathrm{ab}}$ \\
\hline Pluit & $0.00 \pm 0.00^{b}$ & $0.00 \pm 0.00^{c}$ \\
\hline Jatinegara & $0.40 \pm 0.89^{b}$ & $0.83 \pm 2.04^{c}$ \\
\hline Anyar & $0.00 \pm 0.00^{b}$ & $27.00 \pm 28.42^{a}$ \\
\hline Bogor & $0.00 \pm 0.00^{b}$ & $7.00 \pm 8.05^{c}$ \\
\hline Jambu Dua & $1.00 \pm 2.24^{b}$ & $11.17 \pm 11.36^{b c}$ \\
\hline Gunung Batu & $3.40 \pm 7.60^{b}$ & $26.17 \pm 8.80^{\mathrm{ab}}$ \\
\hline
\end{tabular}

Keterangan: Angka yang diikuti huruf superscript berbeda pada kolom yang sama menunjukkan berbeda nyata $(p<0.05)$

Tabel 4 Prevalensi (\%) kecacingan berdasarkan jenis cacing

\begin{tabular}{lcr}
\hline \multicolumn{1}{c}{ Jenis Endoparasit } & \multicolumn{2}{c}{ Prevalensi } \\
\cline { 2 - 3 } Railletina echinobothrida & Jakarta & Bogor \\
Railletina tetragona & 56 & 70 \\
Heterakis gallinnarum & 32 & 55 \\
Hymenolepis carioca & 16 & 30 \\
Ascaridia galli & 16 & 0 \\
Hymenolepis cantaniana & 4 & 20 \\
Railletina cesticillus & 0 & 20 \\
\hline
\end{tabular}

tradisional Pekanbaru yang menunjukkan dari 42 sampel usus ayam kampung yang diperiksa 26 mengalami kecacingan (Rismawati et al. 2013).

Prevalensi ayam yang terinfestasi cacing di pasar di Bogor dan Jakarta memiliki perbedaan yang signifikan. Rata-rata prevalensi kecacingan di pasar Jakarta sebesar $56 \%$ (Tabel 1) sedangkan pasar yang ada di Kota Bogor sebesar 70\% (Tabel 2). Hal ini menunjukkan bahwa ayam kampung yang dijual di pasar tradisional Bogor memiliki prevalensi kecacingan yang lebih tinggi dibandingkan pasar tradisional di Jakarta.

Cukup tingginya prevalensi kecacingan yang ditemukan dapat disebabkan oleh ayam mengalami kontak yang sering terhadap sumber infeksi. Ayam kampung memenuhi kebutuhan nutrisi mereka dengan mencari makan dari satu tempat ke tempat lain di lapisan superfisial tanah. Tanah tersebut dapat terkontaminasi, salah satunya oleh serangga atau cacing tanah yang dapat menjadi inang antara parasit cacing yang menyerang unggas (Ashenafi dan Eshetu 2004).

Prevalensi kecacingan di pasar Pasar Minggu sangat jauh berbeda dari prevalensi endoparasit di pasar Pluit hal ini disebabkan asal ayam kampung yang berbeda. Ayam yang dipotong di pasar Pasar Minggu berasal dari peternak yang memelihara ayam secara ekstensif atau semi intensif. Sedangkan ayam di pasar Pluit merupakan ayam yang berasal dari peternakan ayam secara intensif.

Sistem peternakan secara ekstensif dilakukan dengan cara membiarkan ayam secara bebas untuk mencari makan sendiri. Sebaliknya dengan sistem peternakan yang intensif ayam berada didalam kandang dan diberi makan sesuai dengan kebutuhan (Rasyaf 2011). Menurut pendapat Supriatna (2010) ayam yang diternakkan secara intensif lebih tinggi produksinya dan hanya sedikit yang mengalami infestasi kecacingan daripada yang diternakkan secara ekstensif. Hal ini disebabkan karena ayam yang diternakkan secara ekstensif punya potensi lebih besar untuk membawa dan menebarkan parasit dari lingkungan tempat ayam biasa mencari makan.

Rataan populasi kelas nematoda paling tinggi berada pada pasar Palmerah dan pasar Pasar Minggu di Jakarta (Tabel 3). Hasil rataan populasi dikedua pasar tersebut menunjukkan hasil yang tidak berbeda nyata namun berbeda nyata dengan pasar lainnya. Sedangkan hasil rataan kelas cestoda paling tinggi berada pada pasar Anyar di Bogor. 
Tabel 5 Perbandingan jumlah cacing (ekor) di Jakarta dan Bogor

\begin{tabular}{llcc}
\hline & \multicolumn{2}{c}{ Jenis Parasit } & \multicolumn{2}{c}{ Jumlah Cacing } \\
\cline { 3 - 4 } Nematoda & Ascaridia galli & Jakarta & $0.00 \pm 0.00^{\mathrm{b}}$ \\
& Heterakis gallinarum & $1.36 \pm 4.28^{\mathrm{b}}$ & $1.10 \pm 3.91^{\mathrm{b}}$ \\
& Hymenolepis cantaniana & $21.08 \pm 73.04^{\mathrm{a}}$ & $0.60 \pm 1.67^{\mathrm{b}}$ \\
& Hymenolepis carioca & $0.04 \pm 0.20^{\mathrm{b}}$ & $1.90 \pm 3.84^{\mathrm{b}}$ \\
& Railletina cesticillus & $1.12 \pm 3.46^{\mathrm{b}}$ & $0.50 \pm 1.10^{\mathrm{b}}$ \\
& Railletina echinobothrida & $0.00 \pm 0.00^{\mathrm{b}}$ & $9.45 \pm 10.62^{\mathrm{a}}$ \\
& Railletina tetragona & $3.56 \pm 5.78^{\mathrm{b}}$ & $2.05 \pm 2.39^{\mathrm{b}}$ \\
\hline
\end{tabular}

Keterangan: Angka yang diikuti huruf superscript berbeda pada kolom yang sama menunjukkan berbeda nyata ( $p<0.05$

\section{Prevalensi Kecacingan berdasarkan Jenis Cacing}

Jenis Endoparasit yang paling sering menyerang ayam kampung adalah Railletina echinobothrida (Tabel 4). Hasil penelitian menunjukkan spesies cacing dari kelas cestoda lebih banyak ditemukan. Menurut Rismawati et al. (2013) cacing cestoda merupakan yang paling sering menginfestasi ayam kampung yang di jual di pasar tradisional Pekanbaru. Hal ini disebabkan lingkungan tempat tinggal ayam terdapat banyak serangga yang merupakan inang antara Railletina sp.

Hasil penelitian pada Tabel 5 menunjukkan rataan jumlah cacing terbanyak di pasar di Jakarta adalah Heterakis gallinarum. Hal ini dapat terjadi karena Heterakis gallinarum memiliki siklus hidup yang langsung dengan waktu yang relatif cepat. Telurtelur berembrio keluar bersama feses dan berkembang menjadi telur infektif sekitar 2 minggu. Ketika telur yang infektif tertelan inang yang peka maka telur akan menetas melalui usus halus. Larva tersebut dapat mencapai sekum melalui lumen usus halus dimana mereka berkembang menjadi cacing dewasa dalam waktu 24 jam (Kurniawan et al. 2010).

Rataan jumlah cacing terbanyak di pasar yang berada di daerah Bogor adalah Railletina echinobothrida (Tabel 5). Hal ini menunjukkan populasi spesies tersebut lebih banyak ditemukan pada pasar yang berada di Bogor. Banyaknya Railletina sp disebabkan mudahnya aksesibilitas dari inang perantara berupa lalat, kumbang dan semut di halaman tempat ayam kampung tinggal. Infeksi Cestoda pada unggas menyebabkan terhambatnya pertumbuhan, diare enteritis, perdarahan, dan hipovitaminosis B (Dar dan Tanveer 2013).

\section{Identifikasi Endoparasit Cacing}

Berdasarkan hasil pemeriksaan terdapat tujuh spesies cacing yang ditemukan. Ketujuh spesies ter- sebut berasal dari kelas nematoda dan cestoda. Spesies kelas nematoda yang ditemukan adalah Ascaridia galli dan Heterakis gallinarum. Sedangkan spesies kelas cestoda yang ditemukan adalah Hymenolepis cantaniana, Hymenolepis carioca, Railletina cesticillus, Railletina echinobothrida, dan Railletina tetragona. Cacing dari kelas Trematoda tidak ditemukan pada penelitian ini, hal ini dapat disebabkan karena sedikitnya inang antara dari Trematoda di sekitar kandang ayam (Suhaila et al. 2015).

Cacing R. echinobothrida, R. tetragona, dan R. cesticillus berasal dari genus yang sama namun memiliki sedikit perbedaan. Salah satu perbedaannya adalah ukuran dan bentuk rostellum dan sucker. Cacing R. echinobothrida memiliki bentuk rostellum dan sucker yang bulat, sementara cacing $R$. tetragona memiliki rostellum yang bulat kecil dan sucker ovoid. Sedangkan cacing R. cesticillus memiliki kepala yang tidak berleher serta rostellum besar dan sucker yang tidak berkait (Nandi dan Samanta 2010).

Cacing R. echinobothrida dapat memiliki panjang sampai $25 \mathrm{~cm}$, dengan sucker 8-15 baris kait dan rostelum terdiri 2 baris kait dengan masing-masing 200250 kait (Saif et al. 2008). Cacing R. tetragona memiliki panjang sampai $25 \mathrm{~cm}$ namun memiliki sucker dengan 8-12 baris kait dan rostelum terdiri 2 baris kait dengan masing-masing 90-130 kait (Mandal 2012). Berbeda dengan dua spesies lainnya cacing $R$. cesticillus memiliki panjang mencapai $15 \mathrm{~cm}$ dan rostelum yang lebar dengan 400-500 kait kecil (Saif et al. 2008).

Perbedaan yang kedua terletak pada genital pore unilateral. Cacing R. echinobothrida memiliki genital pore unilateral yang terletak di mediolateral sampai posteriolateral sedangkan $R$. tetragona dan $R$. cesticillus terletak di anterolateral sampai mediolateral di setiap segmen (Wehr 1972). Perbedaan terakhir yang dapat dilihat adalah jumlah telur di setiap kapsul telur yang ada di segmen gravid. Cacing $R$. tetragona 

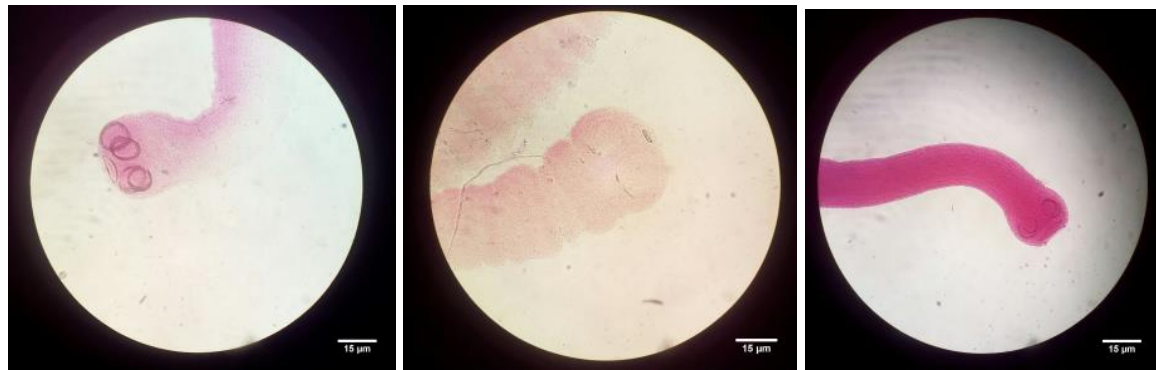

Gambar 1 Morfologi scolex. (a) Railletina echinobothrida, (b) Ralletina tetragona, (c) Railletina cesticillus
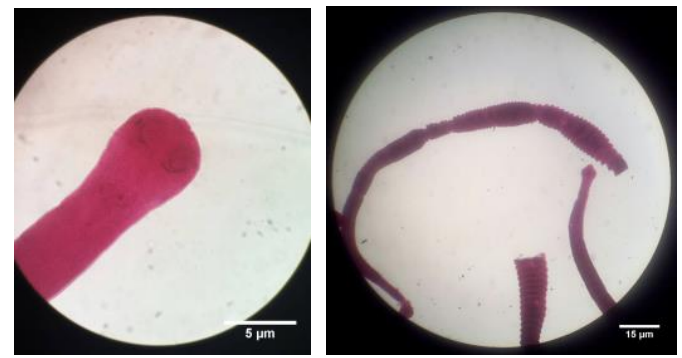

Gambar 2 Morfologi scolex. (a) Hymenolepis carioca, (b) Hymenolepis cantaniana
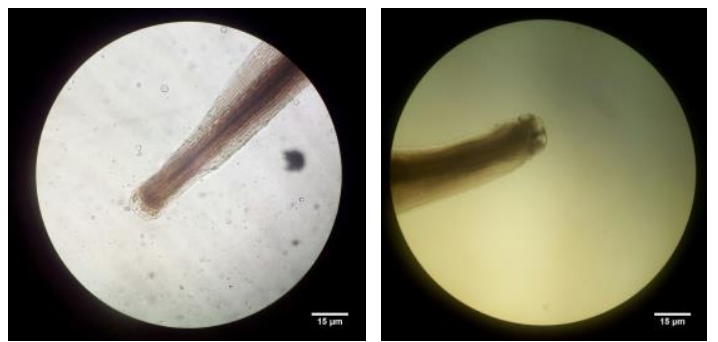

Gambar 3 Morfologi anterior. (a) Ascaridia galli, (b) Heterakis gallinarun

memiliki 6-12 telur di setiap kapsulnya (Mandal 2012). Cacing R. echinobothrida memiliki telur sebanyak 8-12 telur, sedangkan $R$. cesticillus memiliki satu telur di setiap kapsulnya (Saif et al. 2008). Menurut Butboonchoo dan Wongsawad (2017), berdasarkan perbedaan morfologi dan tekhnik HATRAPD (High annealing temperature-random amplified polymorphic DNA) R. echinobothrida memiliki hubungan kekerabatan yang lebih dekat dengan $R$. tetragona dibandingkan dengan $R$. cesticillus.

Banyaknya infeksi cacing Railletina ini disebabkan oleh banyaknya inang antara yang hidup di sekitar tempat tinggal ayam. Inang antara R. echinobothrida dan R. tetragona merupakan semut dari genus Tetramorium dan Pheidole (Soulsby 1982). Ayam akan mengalami infeksi setelah memakan semut yang mengandung cysticercoid (Mandal et al. 2004). Inang antara dari $R$. cesticillus merupakan kumbang (Fischer dan Say 1989). Inang antara alami dari $R$. cesticillus adalah Opatroides frater atau disebut juga kumbang tanah (Velusamy et al. 2014). Cacing $R$. echinobothrida adalah salah satu cacing pita yang paling patogen karena dapat menyebabkan nodul pada usus halus, enteritis hyperplasia terkait dengan pembentukan granuloma sehingga sering menimbulkan nekrosis usus (McDougald 2003).

Cestoda lain yang menginfeksi ayam pada penelitian ini adalah Hymenolepis cantaniana dan Hymenolepis carioca. Cacing $H$. cantaniana memiliki panjang mencapai $2 \mathrm{~cm}$, sucker dan rostelum yang tidak berkait dan genital pore unilateral yang berada pada posisi anterolateral sampai mediolateral. Cacing $H$. carioca memiliki panjang $3-8 \mathrm{~cm}$ dengan ukuran lebar segmen 3-5 kali panjang segmen (Wehr 1972). Kedua cacing ini hidup di usus halus ayam dan memiliki inang antara berupa kumbang dan lalat (Fischer dan Say 1989). Infeksi dari Hymenolepis dapat menyebabkan ayam usus mengalami fokal nekrosa dan ptechie hemorrhagi pada ususnya. Selain itu dapat menimbulkan oedema pada usus 
dengan eksudat catarrhalis dan hemorrhagi. Hal ini bisa disebabkan karena seluruh atau sebagian skoleks menembus mukosa usus dan menyebabkan penyumbatan pembuluh darah (Bhownik dan Sinha 1983).

Infeksi Nematoda pada ayam di penelitian ini disebabkan oleh Ascaridia galli dan Heterakis gallinarum. Menurut Soulsby (1982), cacing dewasa A. galli memiliki ukuran sekitar $6-12 \mathrm{~cm}$, terlihat semi transparan dan bewarna putih kekuningan. A. galli memiliki kutikula ekstraseluler yang tebal untuk melindungi membrana plasma hypodermal cacing dewasa dari enzim pencernaan inang (Zaharah et al. 2016). Cacing $A$. galli bejenis kelamin betina dan jantan dapat ditemukan di penelitian ini. Cacing betina $A$. galli berukuran lebih besar daripada yang jantan. Vulva pada cacing betina berada pada bagian tengah tubuh sedangkan bagian ekor pada cacing jantan memiliki caudal alae yang kecil serta beberapa caudal papillae yang pendek dan tebal, serta memiliki spikula (Rahman dan Manaf 2014).

Infeksi $A$. galli terjadi bila ayam menelan telur terinfeksi yang terdapat dalam makanan atau minumannya Zaharah et al. (2016). Cacing tanah juga dapat bertindak sebagai vector mekanis dengan cara menelan telur tersebut dan kemudian cacing tanah dimakan oleh ayam. Ayam yang terinfeksi $A$. galli dapat mengalami penurunan fungsi usus halus dalam menyerap makanan karena terjadi kerusakan pada vili dan sel epitel usus ayam (Zalizar et al. 2006). Geredaghi (2011) dalam Rohmawati (2016) mengatakan, keberadaan $A$. galli dapat menyebabkan penurunan tingkat pertumbuhan, penurunan berat badan, kerusakan mukosa usus yang menyebabkan kehilangan darah dan infeksi usus.

Nematoda yang juga menginfeksi ayam pada penelitian ini adalah Heterakis gallinarum. H. gallinarum hidup di sekum ayam dan memiliki ukuran yang kecil dan bewarna putih. Menurut Rahman dan Manaf (2014), H. gallinarum memiliki mulut dengan 3 bibir dan buccal capsule yang kecil serta vulva terletak di bagian tengah tubuh (Zaharah et al. 2016). Karena hidupnya di sekum, cacing ini dapat menyebabkan kerusakan sekum yang mengakibatkan gangguan dalam reabsorbsi air dan garam organik dan menghambat terjadinya fermentasi oleh bakteri selulolitik (Susilowati 2009). Cacing ini juga dapat menimbulkan peradangan, penebalan mukosa, thyplitis, diare, penurunan berat badan, dan kematian (Permin dan Hansen 1998).

Sama dengan nematoda yang lain, penularan $\mathrm{H}$. gallinarum disebabkan karena inang menelan telur infektif. Cacing tanah dapat menjadi inang antara cacing ini karena dapat melindungi larva selama 1 tahun atau lebih (Kusumamihardja 1992). Menurut Brener et al. (2006), H. gallinarum dapat menjadi inang antara dari Histomonas meleagridis yang menyerang unggas (black head disease). Protozoa ini dapat hidup dalam telur $\mathrm{H}$. gallinarum selama telur itu hidup (Akoso 1998).

"Penulis menyatakan tidak ada konflik kepentingan dengan pihak-pihak yang terkait dalam penelitian ini".

\section{DAFTAR PUSTAKA}

Akoso BT. 1998. Kesehatan Unggas. Yogyakarta (ID): Kanisius.

Anwar H dan Zia UR. 2002. Effect of Ascaridia galli infestation on electrolytes and vitamins in chicken. Journal of Biological Science. 2(10):650-651.

Ashenafi H, Eshetu Y. 2004. Study on gastrointestinal helminths of local chicken in Central Ethiopia. Revue de Medecine Veterinaire. 155(10): 504-507.

Balqis U, Hambal M, Utami CS. 2014. Gambaran histopatologis usus ayam kampung (Gallus domesticus) yang terinfeksi Ascaridia galli secara alami. Jurnal Medika Veteriner. 8(2).

Bhownik MK, Sinha PK. 1983. Studies on the Pathology of Taeniasis in domestic fowl. Indian Veterinary Journal. 60: 6-8.

Brener B. Tortelly R, Menezes RC, Muniz-Pereira LC, Pinto RM. 2006. Prevalence and pathology of the nematode Heterakis gallinarum. The trematode Paratanaisia bragai, and the protozoa Histomonas meleagridis in the turkey, Melea gallopavo. Mem Inst Oswaldo Cruz. 101(6): 677-681. doi:10.1590/S0074-02762006000600017

Butboonchoo P, Wongsawad C. 2017. Occurance and HAT-RAPD analysis of gastrointestinal helminthes in domestic chickens (Gallus gallus domesticus) in Phayao province, northern Thailand. Saudi Journal of Biological Science. 24(1):30-35. doi : 10.1016/j.sjbs.2015.09.002

Dar JA, Tanveer S. 2013. Prevalence of cestode parasites in free-range backyard chickens (Gallus gallus domesticus) of Kashmir, India. Agriculture and Biology Journal of North America. 4(1): 67-70. doi:10.5251/abjna.2013.4.1.67.70.

Fischer MS dan Say RR. 1989. Manual of Tropical Veterinary Parasitology. Oxford (UK): CAB international. 
Geredaghi Y. 2011. Identification of immunogenic relevant antigens in the excretory-secretory (ES) products of Ascaridia galli larvae. Advances in Environmental Biology. 5(6): 1120-1126.

Gillespie RJ. 2004. Modern Livestock and Poultry Production. $7^{\text {th }}$. Washington DC (US): Thomson Learning Inc.

He S, Susilowati V EHS, Purwati E, Tiuria R. 1991. Taksiran kerugian produksi daging akibat infeksi alamiah cacing saluran pencernaan pada ayam buras di Bogor dan sekitarnya. Hemera Zoa. 74:56-64.

Isdiyanto DA. 2002. Analisis saluran pemasaran yam kampung (Gallus domesticus) di Jakarta Selatan provinsi DKI Jakarta [skripsi]. Bogor (ID): Institut Pertanian Bogor.

Kurniawan MC, Suzanna E, Retnani EB. 2010. Inventarisasi cacing parasitic saluran pencernaan elang jawa (Spizaetus bartelsi Stressman, 1924) dan Elang Brontok (Spizaetus cirrhatus Gmelin, 1788) di habitat eks-situ. Media Konsevasi. 15(3):120-125.

Kusumamihardja S. 1992. Parasit dan Parasitosis pada Hewan Ternak dan Hewan Piaraan di Indonesia. Bogor (ID): Pusat Antar Universitas Bioteknologi IPB

Loliwu YA, Thalib I. 2012. Prevalensi penyakit cacing pada ayam buras di desa Taende dan Tomata kecamatan Mori Atas kabupaten Morowali. Jurnal Agripet. Vol 9.

Mandal AB, Yadav AS, Johri JS, dan Pathak NK. 2004. Nutrition and Diseases Management of Poultry. New Delhi (IND): IBDC publisher

Mandal SC. 2012. Veterinary Parasitology at a Glance. New Delhi (IND): IBDC publisher.

McDougald LR. 2003. Cestodes and trematodes. Di dalam: Saif YM, Barnes HJ, Fadly AM, Glisson JR, McDougald LR, Swayne DE, editor. Disease of Poultry $11^{\text {th }}$ ed. Iowa State (US): Blackwell Publishing.

Nandi S dan Samanta S. 2010. Poultry Diseases at a Glance. New Delhi (IND): IBDC publisher.

Parede L, Zainuddin D, Huminto H. 2005. Penyakit menular pada intensifikasi unggas lokal dan cara penanggulangannya. Di dalam: Parede L, Zainuddin $\mathrm{D}$, Huminto $\mathrm{H}$, editor. Lokakarya Nasional Inovasi Teknologi Pengembangan Ayam Lokal; Bogor, Indonesia. Bogor (ID): Pusat Penelitian dan Pengembangan Peternakan

Permin A, Hansen JW. 1998. Epidemiology diagnosis and control poultry parasites. FAO Animal Health Manual. Roma (IT): FAO United Nation.
Rahman WA, Manaf NH. 2014. Description on the morphology of some nematosed of the Malaysian domestic Chicken (Gallus domesticus) Using Scanning electron microscopy. Malaysian Journal of Veterinary Research. 5(1):35-42. doi: 10.5829/idosi.gv.2014.12.01.76116.

Rasyaf M. 2011. Beternak Ayam Kampung. Jakarta (ID): Penebar Swadaya.

Rismawati, Yusfiati, Radith M. 2013. Endoparasit pada usus ayam kampung (Gallus domesticus) di pasar tradisional Pekanbaru [skripsi]. Fakultas Matematika dan Ilmu Pengetahuan Alam Universitas Riau.

Rohmawati. 2016. Prevalensi Ektoparasit dan endoparasit pada itik yang dipelihara secara intensif dan semi intensif [skripsi]. Semarang (ID): Universitas Negeri Semarang.

Saif YM, Fadly AM, Gilisson JR, Mc Dougald LR, NoIan LK, Swayne DE. 2008. Disease of Poultry. Oxford (UK): Blackwell Publishing,

Smith VH, Jones TP, Smith MS. 2005. Host nutrition and infectious disease: an ecological view. Frontiers in Ecology and the Environment. 3(5):268274. doi: 10.1890/15409295(2005)003[0268: HNAIDA] 2.0.CO;2.

Soulsby EJL. 1982. Helminths, Arthropods and Protozoa of Domestic Animals. $8^{\text {th }}$ ed. London (UK): The English Language Book Society and Bailliere Tindall.

Suhaila AH, Sabrina DL, Nik Ahmad Irwan Izzaudin NH, Hamdan A, Khadijah S. 2015. Study of parasites in commercial free-range chickens in northern peninsular Malaysia. Malaysian Journal of Veterinary Research. 6:53-64.

Sulandari S, Zein MSA, Paryanti S, Sartika T, Astuti M, Widjastuti T, Sudjana E, Darana S, Setiawan I, Garnida D. 2007. Sumberdaya genetic ayam lokal Indonesia. Keanekaragaman sumberdaya hayati ayam lokal indonesia: manfaat dan potensi. Jakarta (ID): Pusat Penelitian Biologi Lembaga IImu Pengetahuan Indonesia. Hal 45-67.

Supriatna E. 2010. Strategi pengembangan ayam local berbasis sumberdaya local dan berwawasan lingkungan. Makalah. Dalam: Seminar Nasional Unggas Lokal ke IV Di Fakultas Peternakan UNDIP, 7 Oktober.

Susilowati, Sri MS, Ajik A. 2009. Histopatologi sekum Itik Jawa (Anas javanica) yang terinfeksi Echinostoma sp. [skripsi]. Surabaya (ID): Universitas Airlangga. 
Tabbu CR. 2003. Penyakit Ayam dan Penanggulangannya. Yogyakarta (ID): Kanisius.

Velusamy R, Basith SA, Harikrishnan TJ, Ponnudurai G, Anna T, Ramakrishnan S. 2014. Ground beetle, Opatroides frater (Coleoptera) as natural intermediate host for the poultry tapeworm, Railletina cesticillus. Journal of Parasitic Diseses. 38(1):128-131. doi : 10.1007/s12639-012-0202-4

Wehr EE. 1972. Disease of Poultry. Hofstad MS, Calnek BW, Helmboldt CF, Reid WM, Yoder HW, editor. Iowa (US): The lowa State University Press.

Wuri DA. 2001. Fluktuasi populasi nematoda saluran pencernaan ayam kampung pada bulan kering dan bulan basah di wilayah kabupaten bogor [skripsi]. Bogor (ID): Institut Pertanian Bogor.
Zaharah I, Yanti HA, Setyawati TR. 2016. Kepadatan nematoda gastrointestinal itik manila (Cairina moschata) yang dipasarkan di pasar Flamboyan kota Pontianak. Protobiont. 5(3): 41-46.

Zalizar L, Satrja F, Tiuria R, Astuti DA. 2006. Dampak infeksi Ascaridia galli terhadap gambaran histopatologi dan luas permukaan vili usus halus serta penurunan bobot hidup starter. Journal Ilmu Ternak dan Veteriner. 11(3):222-228.

Zalizar LF, Satrija F, Tiuria R, Dewi AA. 2007. Respon ayam yang mempunyai pengalaan infeksi Ascaridia galli terhadap infeksi ulang dan implikasinya terhadap produktivitas dan kualitas telur. Animal Production. 9(2):92-98. 